\title{
Species delimitation IN THE genus QueRcus (FAgAcEAE)
} DELIMITACIÓN DE ESPECIES EN EL GÉNERO QUERCUS (FAGACEAE)

\author{
(1) Susana Valencia-A. \\ Herbario de la Facultad de Ciencias, Departamento de Biología Comparada, Universidad Nacional Autónoma de México, Ciudad \\ de México, Mexico.
}

Author for correspondence: svalencia.a@ciencias.unam.mx

\begin{abstract}
Background: Quercus is recognized as a taxonomically complex genus, but also as a model clade in many important fields in biology, such that a good recognition of its species is necessary. The chosen species concept to use in Quercus will determine the empirical criteria used to recognize them, which will impact several areas of knowledge.

Questions: What are the main sources of variation that hinder the delimitation of species in Quercus? What species concepts we use explicitly to recognize species in Quercus? What is the advantage of using different empirical criteria both integrally and simultaneously in delimitation of species of oaks?

Studied species: Species of Quercus

Method: Bibliographic review of the main sources of variation in Quercus, and the species concepts, specifically those used in Quercus.

Results: Plasticity, convergence, hybridization and introgression, and incomplete divergence were identified as the main sources of variation in oaks. Taxonomic and ecological species concepts are those mainly and traditionally used in Quercus. Syngameons are important to know and understand the biology and evolution of Quercus species. These systems indicate that there are preserved genes that provide coherence and morphologic, ecologic and genetic identity to species, even if hybridization, backcrossing and introgression occur.

Conclusions: Preserved genes that provide coherence to species, suggest using taxonomic, ecologic and genetic concepts to delimit problematic species in species complexes in Quercus. The simultaneous use of data that these concepts support (multicriteria analysis), will give more confidence to get closer to the nature of the species and build an integrative taxonomy.
\end{abstract}

Keywords: Criteria to delimiting species, nomenclature, species concepts, taxonomy.

\section{Resumen}

Antecedentes: Quercus es reconocido como un género taxonómicamente complejo, pero también como un clado modelo, implicando un buen conocimiento y reconocimiento de sus especies. El concepto de especie utilizado en Quercus repercutirá en los criterios empíricos empleados para reconocer especies y en los resultados de su aplicación en diferentes campos.

Preguntas: ¿Cuáles son las principales fuentes de variación que dificultan delimitar especies en Quercus? ¿Cuáles conceptos de especie usamos para reconocer especies en este género? ¿Cuál es la ventaja de utilizar múltiples criterios empíricos simultaneamente para delimitar las especies de encinos?

Especies estudiadas: Especies de Quercus

Método: Revisión bibliográfica de las principales fuentes de variación en Quercus y de conceptos de especie, enfatizando en los usados en Quercus.

Resultados: Se identificó a la plasticidad, convergencia, hibridación e introgresión y divergencia incompleta como las principales fuentes de variación en encinos. Los principales conceptos de especie tradicionalmente utilizados en Quercus son el taxonómico y ecológico. Los singameones son importantes en el conocimiento y entendimiento de la biología y evolución de las especies de Quercus. Estos sistemas permiten conocer que hay genes conservados que proporcionan coherencia, así como identidad morfológica, ecológica y genética a las especies, aun cuando se presente hibridación, retrocruza e introgresión.

Conclusiones: Los genes que proporcionan coherencia a las especies sugieren utilizar los conceptos taxonómico, ecológico y genético en las especies problemáticas del género Quercus. El uso simultaneo de los datos que estos conceptos respaldan, darán más confianza para acercarnos a la naturaleza de las especies y construir una taxonomía integrativa.

Palabras clave: Conceptos de especie, criterios para delimitar especies, nomenclatura, taxonomía. 
Species are the basic units in biological studies (Mayer 1982, Rosell et al. 2010, Bacon et al. 2012, Su et al. 2015), and their recognition through their features, the causes and understanding of their variation are fundamental and challenging in taxonomy (Pinheiro et al. 2018). The chosen species concept will determine the criteria used for recognizing a given taxon, which will impact several aspects such as the areas of species richness, conservation and management of areas, among others (Peterson \& Navarro-Sigüenza 2001).

There are many species concepts, all of them contributing to the knowledge and understanding of living organisms and their biology. However, none of these concepts is universally accepted because of issues widely discussed in previous studies (Mayden 1997, De Queiroz 2007, Aldhebiani 2018). De Queiroz (2007, 2011) highlighted that the main problem when considering a species concept unanimously lies in the fact that researchers consider the same species with different temporal perspectives, suggesting that the solution is to consider a species as separately evolving metapopulation lineages from one divergence process to the next. This criterion is a feature that the analyzed concepts have in common and was named by De Queiroz as the unified concept of species, because it arises from unifying the criteria that the analyzed concepts have in common: lineages evolving separately. Likewise, it suggests that species can be delimited through multiple lines of evidence, using for instance properties such as monophyly, reproductive isolation or diagnosability. According to Naomi (2011), the proposal of De Queiroz is similar to the evolutionary concept of species previously proposed by Mayden (1997) and considers it a synonym of this concept. The work of De Queiroz (2007) has the merit of emphasizing the separation of the conceptualization of species and the empirical criteria used for their delimitation.

Currently, there is a tendency to use morphologic, genetic, ecologic and geographic criteria together to define species objectively (Ruiz-Sanchez \& Sosa 2010, Reeves \& Richards 2011, Bacon et al. 2012, Su et al. 2015, Pinheiro et al. 2018). This has been called the multicriteria method, multiple evidence method or integrative method (Zeng et al. 2010, Bacon et al. 2012, Su et al. 2015). Such approaches in the delimitation of species are consistent with the proposal of De Queiroz (2007) of using multiple lines of evidence simultaneously, thus shedding light on this challenging task when applied to taxonomically complex groups, such as the genus Quercus, by giving more support and objectivity. In addition, these methods prove helpful to know and to understand their history, biology, function, and evolution.

Given their ecological, evolutionary and economic importance, oaks are widely studied and are considered as a model in many important fields in biology such as ecology, biogeography and evolution (Marsico et al. 2009, Zeng et al. 2010, Neophytou et al. 2010, Torres-Miranda et al. 2011, Lee et al. 2014, Gutiérrez \& Trejo 2014, Ramírez-Toro et al. 2017, Cannon \& Pettit 2019, Cavender-Bares 2019), and a keystone in ecosystems (Valencia-A. \& Gual-Díaz 2014), which is why defining and differentiating the species of the genus is fundamental.

The species of the genus Quercus, also known as oaks, usually present high morphological variation (Valencia-A. 2004, Nixon 2006, Aldrich \& Cavender-Bares 2011, Sork et al. 2016) and comprise several taxonomic complexes such as those studied by Nixon \& Muller (1993), Spellenberg \& Bacon (1996), Romero (2006), Vázquez \& Nixon (2013), Valencia-A. et al. (2015, 2016), and Sabás-Rosales et al. (2017). This has resulted in treating the species concept in the genus Quercus in a special way (Trelease 1924, Muller 1942, Burger 1975, VanValen 1976, Grant 1981, Aldrich \& Cavender-Bares 2011, Simeone et al. 2013).

The a priori recognition of species in many studies of oaks is based on the taxonomic species concept, that is, in the macroscopic and microscopic morphology in which empirical evidence requires the revision of dichotomous keys and identification of morphology in both fresh and herbarium specimens. However, given that characters evolve at different rates, using morphology alone would imply different limits than using simultaneously genetics, geography, anatomy or ecology data (Peterson \& NavarroSigüenza 2001).

With the improvement of methods, techniques and study systems, especially in the species of Quercus, new evidence has emerged giving us better insight and understanding of the organization and biology of oaks, thus advancing towards a more precise recognition of its species and an integrative taxonomy. This evolution of knowledge makes it convenient to revise the concept of species in Quercus, which will allow greater objectivity in the delimitation of species and a supported mapping of the species among the phylogenetic relationship in the group. Therefore, the revision presented here will highlight the advantages of using different empirical criteria both integrally and simultaneously in the recognition of species of oaks, resulting in the usage of a binomial name with biological meaning. As a starting point, the possible origins of the problem in the recognition of species among oaks are highlighted, followed by the revision of species concepts used explicitly for the genus Quercus. It is important to clarify that neither the philosophical bases and ontology of the concepts, nor the methods used for the analysis of criteria, are discussed. For the latter topic, the study of $\underline{\text { Sites }}$ \& Marshall (2004) is recommended. 


\section{Results}

Problem sources. The identification of species in a taxonomic context methodically implies the recognition of morphological features, which usually present high intraspecific variation within the genus Quercus, resulting in problems of species delimitation. Among the main causes of such variation are plasticity, convergence, hybridization and introgression, and incomplete divergence.

Plasticity. This is the response of a particular genotype to the environment or to the conditions to which an organism is subjected, determining the niche of that organism (Pigliucci 2001, Palacio-López \& Rodríguez-López 2007). Plasticity can work in an adaptive way (Abrams 1994, Aldrich \& Cavender-Bares 2011) and it is crucial for the persistence of long-lived species (Valladares et al. 2002, Ramírez-Valiente et al. 2010) such as oaks, increasing the fitness of individuals.

High genetic variability among species of the genus Quercus has resulted in an advantage by its expression, not only as chemical, physiological and developmental characters (Aldrich \& Cavender-Bares 2011, CavenderBares \& Ramírez-Valiente 2017, Ramírez-Valiente \& Cavender-Bares 2017), but as morphological features as well (habit, indumentum, size, shape of leaves, buds and fruits), according to the environmental conditions in which organisms develop. Oak leaves have particularly high plastic phenotypes, leaves can present different shapes in one individual, among individuals of the same population, and in populations of the same species, such as $Q$. elliptica and $Q$. castanea (Figure 1A-1C) both species with wide distribution in Mexico; in the former Maya-García et al. (2020) found that the variation of the leaf length and thickness and specific leaf area are correlated with the seasonality of temperature, precipitation, elevation and aridity throughout its distribution range. Kusi \& Karsai (2020) recognized that in oaks, the outer leaves with a higher exposure to sunlight are usually different (smaller and with lobules) from those that are in shade (larger and with entire margin) on the same tree, given the differences of light availability and microclimate. The plasticity among leaves coming from sprouts of most oaks differ significantly from the leaves of the rest of the tree or other individuals from the same species, leading to the determination of different species based on specimens coming from the same tree (pers. obs.). In spite of leaf variation, in classic taxonomy of Quercus, the main characters used for the classification and recognition are morphological leaf traits, especially shape, margin, apex, base, number of veins and indumentum; even, some studies have found that the shape of leaves, analyzed through geometric morphometric methods, could be used to delimit species and to recognize hybrids (Fortini et al. 2015, Viscosi 2015, Liu et al. 2018, López-de Heredia et al. 2018, Albarrán-Lara et al. 2019).

Convergence. Plants that are systematically distant can present certain morphological similarities (Font-Quer 1963), usually from growing in similar environmental conditions. Numerous cases of convergence in leaf morphology of oaks have been studied, such as Quercus costaricensis and $Q$. bumelioides both from montane rain forest at Cordillera de Talamanca, in Costa Rica, which can be confused due to the shape of the leaves, despite belonging to different sections (Nixon 2006, Hipp et al. 2018, Rodríguez-Correa et al. 2018). Another similar case is that of $Q$. meavei, $Q$. paxtalensis and Q. corrugata with a similar shape of the leaves (Figure 1D-F), and also from montane rain forest but in Mexico. Q. crassipes and $Q$. deserticola could be confused with $Q$. castanea since its leaves can be indistinguishable in similar environmental conditions, do not matter belong to different sections (Figure 1G-I). Some shrubby white oak species of California that grow in dry habitat, open chaparral and in close geographical proximity, are similar in the size of leaves, texture, and margin (with spiny) (Nixon \& Muller 1997, Ortego et al. 2017). Likewise, shrubby species from semi-arid regions in northeastern Mexico present morphological convergence in several leaf features ( $\underline{\text { Sabás- }}$ Rosales et al. 2017). Some physiological convergences for oaks have also been studied, Cavender-Bares (2019) points out phenotypic similarities and convergences in characters related to the adaptation to fire, humidity and soil fertility in different lineages of oaks that share the same habitat. The presence of annual fruits in different lineages of the section Lobatae is a convergence of some species that thrive in warm-humid locations in southern Mexico and Central America (Nixon 2006), but also this character is present in sections Cyclobalanopsis, Cerris, Ilex, Quercus, Virentes, and Ponticae. Convergent transitions in the amount of leaf retention in oak species (deciduous, briefly deciduous, evergreen) are shown as a response to similar biogeography, climate, and soils (Hipp et al. 2018). Convergences can lead to incorrect determination of species and misinterpretation in the evolution of characters.

Hybridization and introgression. Hybridization is defined as the reproduction of members of genetically different populations (Barton \& Hewitt 1985) and introgression is defined as the incorporation or infiltration of alleles from one species into the gene pool of another species, through hybridization and backcrossing (Anderson 1949, Harrison \& Larson 2014). Both processes occur randomly and spontaneously among many species of the same section of the genus Quercus. These events are usually favored by environmental disturbances (Ortego et al. 2017) and they 
oak species delimitation
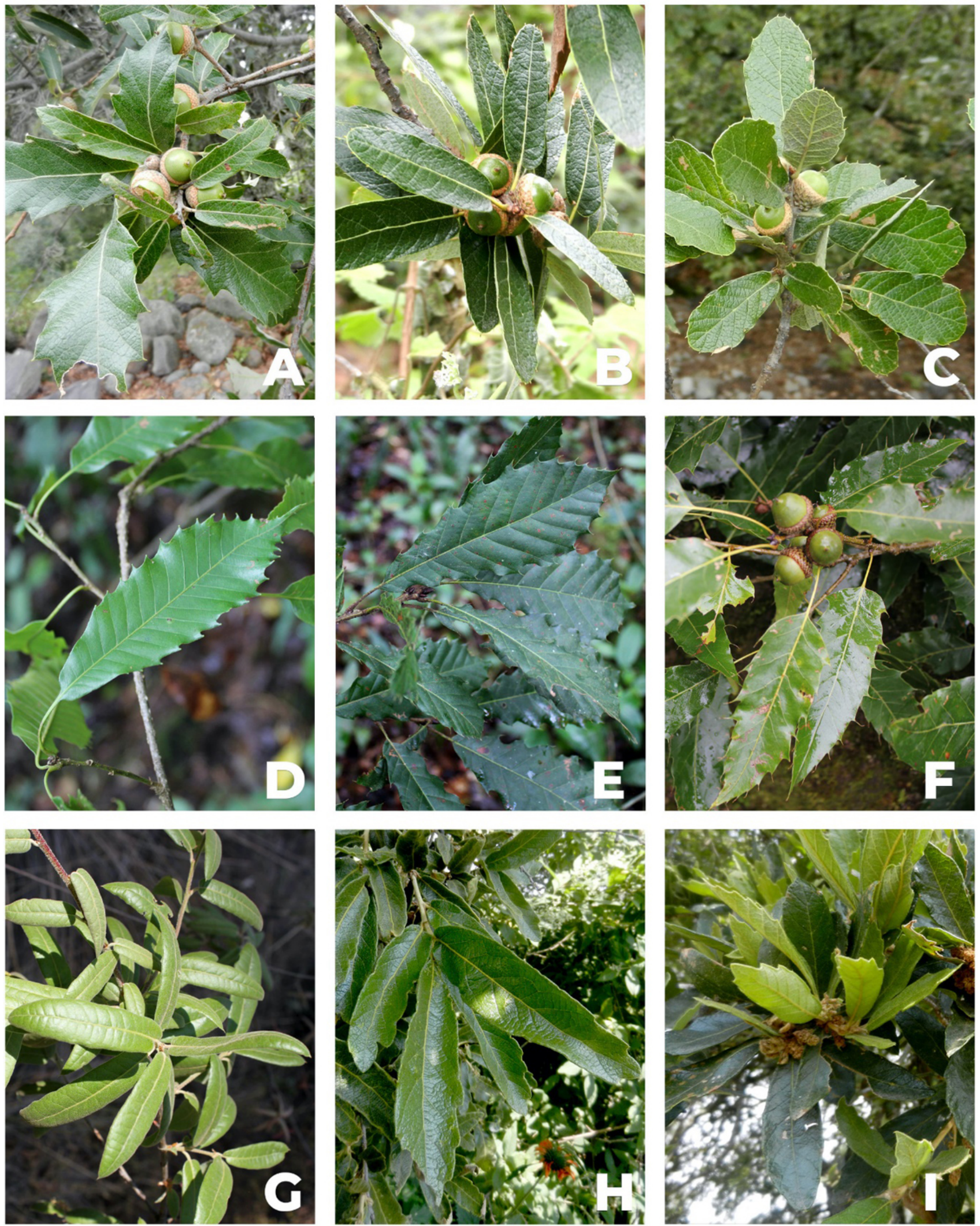

Figure 1. A-C. Variation in the shape of Quercus castanea leaves. D. Quercus corrugata, E. Q. meavei and F. Q. paxtalensis, the last three with similar shape of leaves, and living in montane rain forest. G. Leaves of Quercus crassipes, notice the similarity of leaves with that in picture $1 \mathrm{~B}$ of $Q$. castanea. G, H. Variation in the shape of $Q$. deserticola leaves, notice the similarity with that of $Q$. castanea. 
function as a source of innovation that produces quick adaptations that are useful to face environmental changes (Rieseberg 1997, Abbot et al. 2013, Cannon \& Petit 2019) and to introduce advantageous mutations in a different genetic pool (Leroy et al. 2017).

Hybridization and introgression are processes studied in extant species, but McVay et al. (2017) said that there are ancient introgression events that could have occurred between extinct species or those that are no longer sympatric, such as the ancestors of Ponticae and Roburoid lineages. Suggesting that these processes have played an important evolutionary role in oaks.

Studies on oak hybridization and introgression are generally carried out in two-species systems, however in the last decade, some analyses have identified three- to sixspecies systems with gene flow in American oaks (Dodd \& Afzal-Raffii 2004, Peñaloza-Ramírez et al. 2010, Zhang et al. 2015, Sullivan et al. 2016, Castillo-Mendoza et al. 2018).

Given the interspecific genetic flow, it is common to find individuals with unusual, intermediate or transgressive features suggesting a possible hybrid or backcrossing origin. These individuals might be important in the evolutionary processes within the group, as they work as bridges in the genetic flow of information from one species to another, thus increasing the genetic diversity of the receiver species and possibly originating preadaptations that would allow the occupation of different niches. Despite these evolutionary advantages, the genetic flow among individuals from different species counters the established biological species concept (Mayr 1999) and is considered as the worst scenario to exemplify this concept (Coyne \& Orr 2004). This is also the case for the taxonomic species concept, as there are novel morphological variations in hybrids, including intermediate or transgressive variation (Rieseberg et al. 1999), that are problematic when trying to locate these individuals in a classification system. Although hybrids can be formally named as the International Code of Nomenclature for algae, fungi and plants (Turland et al. 2018) point out, I consider that formally naming each case can be an endless task that would complicate communication in biology.

Incomplete divergence. At the end of the lineage divergence process, some features become clearly distinguishable among the divergent lineages, gametes and breeding systems become incompatible and the lineages colonize different habitats (De Queiroz 2007). But while the lineages are diverging, their characters undergo several evolutionary states, because the divergence is a gradual process that starts with the incipient segregation of populations until their complete separation, without order and asynchrony in the evolution of their properties. The genus Quercus comprises species that diverged recently (Hipp et al. 2018, 2020). In the American tropics, the regions with most diversity, it has been proposed that divergence of extant species started approximately 10 million years ago, in the second half of the Miocene and extending towards the Pliocene (Hipp et al. 2018, 2020), although for some other tropical species of the section Virentes, divergence could be more recent (Gugger \& Cavender-Bares 2013, Cavender-Bares et al. 2015). The divergence of the genus Quercus is related to a rapid evolution caused by preadaptive genetic variation, and availability of different habitats to colonize (Hipp et al. 2018, Cavender-Bares 2019), producing isolated populations that diverge due to their flourishing in different environments. Relatively recent divergence can present weak reproductive barriers and hybridization may still be possible, as in many cases of oaks. An incomplete or recent divergence can make some of the attributes not entirely discrete, making species recognition more difficult, as the case of $Q$. magnoliifolia and $Q$. resinosa with recent divergence (Hipp et al. 2020), and which show morphological and ecological differentiation from each other, but low levels of genetic differentiation (AlbarránLara et al. 2019).

Concepts of species used in Quercus. Among the first investigators who used explicitly the taxonomic concept in the genus Quercus are Trelease (1924) and Muller (1942). They recognized the taxonomic species concept based on phenetic discrete and separated units due to the discontinuity in the variation (Stace 1978). Muller (1942) had problems when deciding whether a recognized group represents a species or variety (the level given), not the identification of discontinuities and groups themselves. The hierarchical level given to taxonomic groups has been controversial throughout the history of taxonomy, including sometimes phylogenies of big groups (Mishler \& De Luna 1997). Muller (1942) uses a broader species concept than Trelease, as he considers varieties, forms and some species described by Trelease as simple variations of species.

Grant (1971), Burger (1975) and Hardin (1975) questioned the usage of the biological species concept in oaks, due to the frequent hybridization between different species. They highlighted that this concept could imply a complex system of crossing populations called syngameon, a group of species that present interspecific genetic flow under changing environmental conditions, but with each species preserving their morphological integrity (Cannon \& Petit 2019), thus allowing its recognition as a taxonomic species.

Aldrich \& Cavender-Bares (2011) mentioned that their studies are based on the concept of Wittgenstein published in 1958, which considers a group or set of characters to recognize species, and that are not necessarily at the same 
level (morphologic or genetic). Simeone et al. (2013) considered that in order to define the identity of the species of Quercus, it is necessary to make a thorough revision based on the synergy of multiple data for each taxon, such as ecology, morphology, history and genetics.

On the other hand, based on the variation observed in species of Quercus and the lack of reproductive isolation in some of them, VanValen (1976) highlighted that species should be recognized by the adaptive zone used, and should also present minimum differences from other lineages and evolve separately from all the lineages. The adaptive zone is considered by Anderson (1990) as a similar concept to the ecological niche, which could be recognized through ecological criteria; and niche could be "a term describing the role of a species or population in its ecosystem" (Martínez-Gordillo et al. 2009).

Although there could be speciation without ecological divergence in oaks (Cavender-Bares 2015), Hipp et al. (2018) show that the niche diversification has driven the high diversification in Mexican oaks. Although the environmental or ecological data are little known or difficult to quantify for some species, ecological niche modeling helps to define the main climatic conditions where the species are present (e.g., Martínez-Gordillo et al. 2009, Ramírez-Preciado et al. 2019, Song et al. 2019). These models have their basis on the relationships between the distribution of a species and its environmental conditions (Booth et al. 2013). Additionally there are several studies on traits related to ecological functional such as leaf size (Cavender-Bares et al. 2015, Maya-García et al. 2020), height of plant (Cavender-Bares et al. 2015), leaf habit (Hipp et al. 2018), hydraulic capacity (Arenas-Navarro et al. 2020) that are linked to niche differentiation in oaks, and are important in local adaptation (Dagnino et al. 2017). These traits together with reproductive isolation can lead to speciation, and show the importance of the ecological niche as part of this process and with the identity of the species, and suggesting that the ecological pattern could be useful to enable the recognition of species limits as the Ecological Species Concept points out (VanValen 1976).

The concept of species and binomial nomenclature. Species are considered as evolutionary, ecological, working and communication units, and to consider them as such they must be consistent with what the names represent and allow the organization of knowledge and the retrieval of a functional information system (Trelease 1924, Burger 1975).

Scientific names represent systems with biological significance (Burger 1975). The name is important because it is key in accessing knowledge generated in the referred group, and it symbolizes large amounts of knowledge and comprehension of the group. In this way, it is noteworthy to say that adequate knowledge and information from various sources and levels are then required to assign a name. These sources of information should explain different characteristics of the species in order to delimit, understand them, and thus, translate them easily to morphological features for practical recognition.

Concepts and useful criteria in the recognition of Quercus.In the conceptualization or ontology of the species, the unified species concept proposed by De Queiroz is suitable when considering that species of Quercus are lineages with an origin and destiny, including genetic, morphologic, ecologic, physiologic, chemical and reproductive attributes (and others) that have been developed at different rates throughout history. The phylogeny of American oaks (Hipp et al. 2018) shows species both close to and far from the point of divergence, suggesting different times of origin, which means that species have evolved at different rates with differences in the development of their features.

The previously described concepts for the study of oaks are operational concepts based on the recognition of species mainly through morphological, genetic or ecological features, and that can be visualized as relevant lines of evidence used for delimit species.

If these could be applied simultaneously, they could be a reliable tool to approach the true limits of the species.

An important attribute in the evolution of oaks that should definitely be taken into account is to consider species as part of a syngameon or interspecific reproductive net, where species are undifferentiated even where genetic flow exists through hybridization, backcrossing and introgression (Cannon \& Petit 2019). Belonging to a syngameon confers the opportunity to enhance genetic diversity, and thus preadaptive advantages towards new niches. Cannon \& Petit (2019) published: "The oak syngameon: more than the sum of its parts" and emphasized the potential advantages of belonging to a syngameon, as this is a source system of novelties, genetic diversity, rapid adaptation and high plasticity for all member species, which co-evolve as a whole.

The study of syngameons has allowed us to know and understand better the variation, evolution, reproduction and consequently the biology of species of Quercus, and also that, even though there are events of hybridization and introgression, it is possible to recognize species in Quercus. According to Hipp et al. (2019), during events of hybridization and introgression the complete genome is not always recombined, as some regions may be kept isolated, giving coherence to these species as well as morphological, ecological and genetic identity (Burger 1975, Williams et al. 2001, Lepais et al. 2009, Zeng et al. 2010, Valencia-Cuevas et al. 2014, Gailing \& Curtu 2014, Eaton et al. 2015, Ortego 
et al. 2017, Leroy et al. 2017). According to Leroy et al. (2020), genetic differentiation at species level is restricted to a few genes that give uniform morphology for the recognition of a species, and these may be related to preserved genes corresponding to ecological tolerance to drought, cold and saline soils, and other genes related to biotic interactions and intrinsic barriers, phenology, pollen recognition and growth. The rest of the genetic information seems to be shared among the species of the syngameon (Muir \& Schlötterer 2005, Curtu et al. 2007, Neophytou et al. 2010, Leroy et al. 2017).

\section{Conclusions}

When considering the preserved genes mentioned earlier that provide coherence and morphologic, ecologic and genetic identity, the relevance of using the taxonomic, ecologic and genetic concepts (evolutionary or phylogenetic) is evident. We can take as a starting point the taxonomic concept as the most practical, and in many cases being sufficient, but in other more complex groups it is recommended to include criteria used to define species from all three concepts, that is, multicriteria studies. Conceptually speaking, the unified concept proposed by De Queiroz provides a good frame of reference.

Multicriteria studies are used not only to define the limits, variation and hybridization of species of Quercus as in $Q$. laurina and $Q$. affinis (González-Rodríguez et al. 2004), Q. magnoliifolia and Q. resinosa (Albarrán-Lara et al. 2019); but also to show the evolution of oak species, for example in Section Virentes (Cavender-Bares et al. 2015), Q. chrysolepis (Ortego et al. 2015), Series Agrifoliae (Duncan et al. 2017), Subsection Racemiflorae (McCauley et al. 2019), and Q. elliptica (Maya-García et al. 2020).

Defining and delimiting species of the genus Quercus remains a challenge in many complexes such as Acutifoliae, Microphylla, Crassifoliae and Rugosae (among others). However, breakthroughs in multiple fields of knowledge will allow better understanding of their evolution and biology, with likely positive effects on taxonomy, phylogeny, and conservation.

The multiple species concepts and their usage along with empirical data provide different kinds of information that should all be considered consistent and practical, both simultaneously and integrally, so that species can be recognized. The coexistence of different compatible species concepts for a group and the use of empirical data coming from different levels or sources, will provide further confidence regarding the nature of species (Sangster 2018), contributing to the knowledge and understanding of their biology.

The taxonomic complexity of Quercus and its consideration as a model clade, will promote the discovery of a great deal of new information, and possible changes in the delimitation and recognition of some species and their nomenclature. However, such changes do not correspond to the artificial creation of limits, but to the discovery of new information supporting a robust and integrative taxonomy, with more objective analysis, and which can be considered as the starting point for many other studies. After obtaining new knowledge in different study areas, it is probable that it will be necessary to review the limits of species for adjustments or modifications. Finally, species and their boundaries stand as a refutable hypothesis that is intended to have a better approach to reality based on current knowledge (Raposo et al. 2017, Sangster 2018).

The recognition and delimitation of species of oaks is challenging, but the possibility to know and understand the processes that intervene in their biology through the integral application of multiple criteria and different species concepts will enhance confidence when recognizing, delimiting and renaming species with biological significance. A better understanding of the biology of the species will affect their delimitation and taxonomy, resulting in a positive impact in different studies carried out on Quercus species.

\section{Acknowledgements}

The author wishes to thank Allen Coombes, Jaime Jiménez Ramírez and an anonymous reviewer for comments that improved the manuscript.

\section{Literature cited}

Abbot R, Albach D, Ansell S, Arntze JW, Baird SJE, Bierne $\mathrm{N}$, Joughman J, Brelsford A, Buerkle CA, Buggs R, Butlin RK., Dieckmann U, Eroukhmanoff F, Grill A, Cahan SH, Hermansen JS, Hewitt G, Hudson AG, Jiggins C, Jones J, Keller B, Marczewski T, Mallet J, Martinez-Rodriguez P, Möst M, Mullen S, Nichols R, Norte AW, Parisod C, Pfennig K, Rice AM, Rithchie MG, Seifert B, Smadja CM, Stelkens R, Szymura JM, Väinölä R, Wolf JBW, Zinner D. 2013. Hybridization and speciation. Journal of Evolutionary Biology 26: 229-246. DOI: $\quad$ https://doi.org/10.1111/ j.1420-9101.2012.02599.x

Abrams MD. 1994. Genotypic and phenotypic variation as stress adaptations in temperate tree species: a review of several case studies. Tree Physiolology 14: 833-842. DOI: https://doi.org/10.1093/treephys/14.7-8-9.833

Albarrán-Lara AL, Petit RJ, Kremer A, Caron H, PeñalozaRamírez JM, Gugger PF, Dávila-Aranda P, Oyama K. 2019. Low genetic differentiation between two morphologially and ecologically distinct giant-leaved Mexican oaks. Plant Systematics and Evolution 305: 89-101. DOI: https://doi.org/10.1007/s00606-018-1554-8 
Aldhebiani AY. 2018. Species concept and specitation. Saudi Journal of Biological Sciences 25: 437-440. DOI: https://doi.org/10.1016/j.sjbs.2017.04.013

Aldrich P, Cavender-Bares J. 2011. Quercus. In: C. Kole, ed. Wild crop relatives: Genomic and Breeding Resources, Forest Trees. Berlin: Springer. pp. 89-129. DOI: https://doi.org/10.1007/978-3-642-21250-5_6; eISBN 978-3-642-21250-5

Anderson E. 1953. Introgressive hybridization. Biological reviews 28: 280-307: https://doi.org/10.1111/j.1469-18 5X.1953.tb01379.x

Anderson L. 1990. The driving force: species concepts and ecology. Taxon 39: 375-382. DOI: https://doi.org/10. 2307/1223084

Arenas-Navarro M, García-Oliva F, Terrazas T, TorresMiranda A, Oyama K. 2020. Leaf habit and stem hydraulic traits determine functional segregation of multiple oak species along a water availability gradient. Forests 11, 894. DOI: https://doi.org/10.3390/f11080894

Bacon CD, McKenna MJ, Simmons MP, Wagner WL. 2012. Evaluating multiple criteria for species delimitation: an empirical example using Hawaiian palms (Arecaceae: Pritchardia). BMC Evolutionary Biology 12: 23 DOI: https:/www.biomedcentral.com/ $\underline{1471-2148 / 12 / 23}$

Barton NH, Hewitt GM. 1985. Analysis of hybrid zones. Annual Review of Ecology and Systematics 16: 113-148. DOI: https://doi.org/10.1146/annurev.es.16.110185.0005 $\underline{53}$

Booth TH, Nix HA, Busby JR, Hutchinson MF. 2013. BIOCLIM: the first species distribution modelling package, its early applications and relevance to most current MaxEnt studies. Diversity and Distributions 20: 1-9. DOI: http://doi.org/10.1111/ddi.12144

Burger WC. 1975. The species concept in Quercus. Taxon 24: 45-50. DOI: https://doi.org/10.2307/1218998

Cannon CH, Petit RJ. 2019. The oak syngameon: more than the sum of its parts. New Phytologist 226: 978-983. https://doi.org/10.1111/nph.16091

Castillo-Mendoza E, Salinas-Sánchez D, Valencia-Cuevas L, Zamilpa A, Tovar-Sánchez E. 2018. Natural hybridization among Quercus glabrescens, Q. rugosa and $Q$. obtusata (Fagaceae): Microsatellites and secondary metabolites markers. Plant Biology 21: 110-121. DOI: https://doi.org/10.1111/plb.12899

Cavender-Bares J, González-Rodríguez A, Eaton DAR, Hipp AL, Beulke A, Manos PS. 2015. Phylogeny and biogeography of the American live oaks (Quercus subsection Virentes): a genomic and population genetics approach. Molecular Ecology 24: 3668-3668. DOI: https://doi.org/10.1111/mec.13269

Cavender-Bares J, Ramírez-Valiente JA. 2017. Physiological evidence from common garden experiments for local adaptation and adaptive plasticity to climate in American live oaks (Quercus section Virentes): implications for conservation under global change. In: Gil-Pelegrín E, Peguero-Pina J, SanchoKnapik D, eds. Oaks Physiological Ecology. Exploring the Functional Diversity of Genus Quercus L., Tree Physiology 7. Switzerland: Springer. pp. 107-136. ISNN 1568-2544. ISBN 978-3-319-69099-5, ISBN: 978-3-319-69099-5; DOI: https://doi.org/10.1007/978-3 -319-69099-5 4

Cavender-Bares J. 2019. Diversification, adaptation, and community assembly of the American oaks (Quercus), a model clade for integrating ecology and evolution. New Phytologist 221: 669-692. DOI: https://doi.org/10.1111/ nph.15450

Coyne JA, Orr HA. 2004. Speciation. Sinauer Associates. Suderland, Massachusetts USA. ISBN: 0-87893-091-4

Curtu AL, Gailing O, Finkeldey R. 2007. Evidence for hybridization and introgression within a species-rich oak (Quercus spp.) community. BMC Evolutionary Biology 7: 218. DOI: https://doi.org/10.1186/1471-2148-7-218

Dagnino D, Minuto L, Casazza G. 2017. Divergence is not enough: the use of ecological niche models for the validation of taxon boundaries. Plant Biology 19: 1003-1011.

De Queiroz K. 2007. Species concepts and species delimitation. Systematic Biology 56: 879-886. DOI: https://doi.org/10.1080/10635150701701083

De Queiroz K. 2011. Branches in the lines of descent: Charles Darwin and the evolution of the species concept. Biological Jorunal of the Linnean Society 103: 19-35. DOI: https://doi.org/10.1111/j.1095-8312.2011.01634.x

Dodd RS, Afzal-Rafii Z, 2004. Selection and dispersal in a multispecies oak hybrid zone. Evolution 58: 261-269. DOI: https://doi.org/10.1111/j.0014-3820.2004.tb01643.x

Duncan AH, Keuter A, McVay JD, Hipp AL, Manos PS. 2017. The evolution and diversification of the red oaks of the California floristic province (Quercus section Lobatae, series Agrifoliae). American Journal of Botany 104: 1581-1595. DOI: https://doi.org/10.3732/ajb.1700 $\underline{291}$

Eaton DAR, González-Rodríguez A, Hipp A, CavenderBares J. 2015. Historical introgression among the American live oaks and the comparative nature of tests for introgression. Evolution 69: 2587-2601. DOI: https:// doi.org/10.1111/evo.12758

Font-Quer P. 1963. Diccionario de botánica. Barcelona, España: Editorial Labor. 1244 p.

Fortini P, Di Marzio P, Di Pietro R. 2015. Differentiation and hybridization of Quercus frainetto, $Q$. petrea and $Q$. pubescens (Fagaceae): insights from macromorphological leaf traits and molecular data. Plant Systematicas and Evolution 301: 375-385. DOI: https:// doi.org/10.1007/s00606-014-1080-2 
Gailing O, Curtu L. 2014. Interspecific gene flow and maintenance of species integrity in oaks. Annals of Forest Research. 57: 5-18. DOI: https://doi.org/ $\underline{10.15287 / \text { afr.2014.171 }}$

Gonzáles-Rodríguez A, Arias DM, Valencia S, Oyama K. 2004. Morphological and RAPD analysis of hybridization between Quercus affinis and $Q$. laurina (fagaceae), two Mexican red oaks. Amarican Jorunal of Botany 91: 401-409. DOI: https://doi.org/10.3732/ ajb.91.3.401

Grant V. 1971. Plant Speciation. USA: Columbia University Press. 563 pp. ISBN-10: 0231051131

Gugger FF, Cavender-Bares J. 2013. Molecular and morphological support for a Florida origin of the Cuban oak. Journal of Biogeografphy 40: 632-645. DOI: https:// doi.org/10.1111/j.1365-2699.2011.02610.x

Gutiérrez E, Trejo I. 2014. Efecto del cambio climático en la distribución potencial de cinco especies arbóreas de bosque templado en México. Revista Mexicana de Biodiversidad 85: 179-188. DOI: http://dx.doi.org/ 10.7550/rmb.37737

Hardin JW. 1975. Hybridization and introgression in Quercus alba. Journal of the Arnold Arboretum 56: 336-363.

Harrison RG, Larson EL. 2014. Hybridization, Introgression, and the nature of species Boundaries. Journal of Heredity 105: 795-809. DOI: https://doi.org/ $\underline{10.1093 / \text { ihered/esu033 }}$

Hipp AL, Manos PS, González-Rodríguez A, Hahn M, Kaproth M, McVay JD, Valencia Avalos S, CavenderBares J. 2018. Sympatric parallel diversification of major oak clades in the Americas and the origins of Mexican species diversity. New Phytologist 217: 439-452. DOI: https://doi.org/10.1111/nph.14773

Hipp AL, Manos PS, Hahn M, Avishai M, Bodénes C, Cavender-Bares J, Crowl, AA, Deng M, Denk T, FitzGibbon S, Gailing O, González-Elizondo MS, GonzálezRodríguez A, Grimm GW, Jiang X-L, Kremer A, Lesur I, Mcvay JD, Plomion C, Rodríguez-Correa H, Schulze ED, Simeone MC, Sork VL, Valencia-Avalos S. 2020. Genomic landscape of the global oak phylogeny. New Phytologist 226: 1198-1212. DOI: https://doi.org/ 10.1111/nph.16162

Hipp AL, Whittemore AT, Garner M, Hahn M, Fitzek E, Guichoux E, Cavender-Bares J, Gugger PF, Manos PS, Pearse IS, Cannon CH. 2019. Genomic identity of white oak species in an eastern North American syngameon. Annals of the Missouri Botanical Garden 104: 455-477. DOI: https://doi.org/10.3417/2019434

Kusi J, Karsai I. 2020. Plastic leaf morphology in three species of Quercus: The more exposed leaves are smaller, more lobated and denser. Plant Species Biology 35: 24-37. DOI: https://doi.org/10.1111/1442-1984.12 $\underline{253}$
Lee J-H, Jin D-P, Choi B-H. 2014. Genetic differentiation and introgression among Korean evergreen Quercus (Fagaceae) are revealed by microsatellite markers. Annales Boanici Fennici 51: 39-48. DOI: https://doi.org/ $\underline{10.5735 / 085.051 .0105}$

Lepais O, Petit RJ, Guichoux E, Lovabre JE, Alberto F, Kremer A, Gerber S. 2009. Species relative abundance and direction of introgression in oaks. Molecular Ecology 18: 2228-2242. DOI: https://doi.org/10.1111/ j.1365-294X.2009.04137.x

Leroy T, Roux C, Villate L, Bodénès C, Romiguier J, Paiva JAP, Dossat C, Aury JM, Plomion C, Kremer A. 2017. Extensive recent secondary contacts between four European white oak species. New Phytologist 214: 865-878. DOI: https://doi.org/10.1111/nph.14413

Leroy T, Tougemont Q, Dupouey J-L, Bodénès C, Lalanne C, Belser C, Labadie K, Le Provost G, Aury J-M, Kremer A, Plomion C. 2020. Massive postglacial gene flow between European while oaks uncovered genes underlying species barriers. New Phytologist 226: 1183-1197. DOI: https://doi.org/10.1111/nph.16039

Liu Y, Li Y, Song J, Zhang R, Yan Y, Wang Y, Du FK. 2018. Geometric morphometric analyses of leaf shapes in two sympatric Chinese oaks: Quercus dentata Thunberg and Quercus aliena Blume (Fagaceae). Annals of Forest Science 75: 90. DOI: https://doi.org/10.1007/ s13595-018-0770-2

López-De Heredia U, Duro-García MJ, Soto A. 2018. Leaf morphology of progenies in $Q$. suber, $Q$. ilex, and their hybrids using multivariate and geometric morphometric analysis. Forest-Biogeosciences and Forestry 11: 90-98 DOI: https://doi.org/10.3832/ifor2577-010

Martínez-Gordillo D. Rojas-Soto O, Espinosa de los Monteros A. 2009. Ecological niche modelling as an exploratory tool for identifying species limits: an example based on Mexican muroid rodents. Journal of Evolutionary Biology 23: 259-270. DOI: https://doi.org/ 10.1111/j.1420-9101.2009.01897.x

Marsico TD, Hellmann JJ, Romero-Severson J. 2009. Patterns of seed dispersal and pollen flow in Quercus garryana (Fagaceae) following post-glacial climatic changes. Journal of Biogeography 36: 929-941. DOI: https://doi.org/10.1111/j.1365-2699.2008.02049.x

Maya-García R, Torres-Miranda A, Cuevas-Reyez P, Oyama K. 2020. Morphological differentiation among populations of Quercus elliptica Née (Fagaceae) along an environmental gradient in Mexico and Central America. Botanical Sciences 98: 50-65 DOI: https:// doi.org/10.17129/botsci.2395

Mayden RL. 1997. A hierarchy of species concepts: the denouement in the saga of the species problem. In: Claridge MF, Dawah HA, Wilson M.R. eds. Species: the Units of Biodiversity. London: Chapman and Hall, pp. 381-424. ISBN 0412631202 
Mayer E. 1982. The growth of biological thought: diversity, evolution and inheritance. Cambridge, MA: Belknap Press of Harvard University Press. 992 pp. ISBN 9780674364462

Mayr E. 1999. Systematics and the origin of species from the viewpoint of a zoologist. USA: Harvard University Press. ISBN-10 0674862503

McCauley R, Cortéz-Palomec A, Oyama K. 2019. Species diversification in a lineage of Mexican red oak (Quercus section Lobatae subsection Racemiflorae)- the interplay between distance, habitat, and hybridization. Tree Genetics \& Genomes 15: 27. DOI: https://doi.org/ 10.1007/s11295-019-1333-x

McVay JD, Hipp AL, Manos PS. 2017. A genetic legacy of introgression confounds phylogeny and biogeography in oaks. Proceedings of The Royal Society 284: DOI: https://doi.org/10.1098/rspb.2017.0300

Mishler B, De Luna E. 1997. Sistemática filogenética y el concepto de especie. Boletín de la Sociedad Botánica de México 60: 45-57. DOI: https://doi.org/10.17129/botsci. $\underline{1518}$

Muir G, Schlötterer C. 2005. Evidence for shared ancestral polymorphism rather than recurrent gene flow at microsatellite loci differentiating two hybridizing oaks (Quercus spp.). Molecular Ecology 14: 549-561. DOI: https://doi.org/10.1111/j.1365-294X.2004.02418.x

Muller CH. 1942. The Central American species of Quercus. Washington, DC: United States Department of Agriculture, Miscellaneous Publication 477.

Naomi SI. 2011. On the integrated frameworks of species concepts: Mayden's hierarchy of species concepts and De Queiroz's unified concept of species. Journal Zoological systematics Evolutionary Research. 49: 177-184. DOI: https://doi.org/10.1111/j.1439-0469.2011. $\underline{00618 . x}$

Neophytou C, Aravanopoulos FA, Fink S, Dounavi A. 2010. Detecting interspecific and geographic differentiation patterns in two interfertile oak species (Quercus petraea (Matt.) Liebl. and Q. robur L.) using small sets of microsatellite markers. Forest Ecology and Management 259: 2026-2035. DOI: https://doi.org/10. 1016/j.foreco.2010.02.013

Nixon KC. 2006. Global and Neotropical distribution and diversity of oak (genus Quercus) and oak forest. In: Kappelle M, ed. Ecology and Conservation of Neotropical Montane Oak Forest. Ecological Studies (Analysis and Synthesis), 185. Berlin, Heidelberg: Springer. DOI: https://doi.org/10.1007/3-540-28909-7_1

Nixon KC, Muller CH. 1993. The Quercus hypoxantha complex (Fagaceae) in northeastern Mexico. Brittonia 45: 146-153. DOI: https://doi.org/10.2307/2807497

Nixon KC, Muller CH. 1997. Quercus Linnaeus sect. Quercus. Flora of North America North of Mexico 3:
471-506. http://floranorthamerica.org/ (accessed September 21, 2020).

Ortego J, Gugger PF, Sork VL. 2015. Climatically stable landscapes predict patterns of genetic structure and admixture in the Clifornian canyon live oak. Journal of Biogeography 42: 328-338. DOI: https://doi.org/10.1111/ jbi. 12419

Ortego J, Gugger PF, Sork VL. 2017. Impacts of humaninduced environmental disturbances on hybridization between two ecologically differentiated Californian oak species. New Phytologist 213: 942-955. DOI: https:// doi.org/10.1111/nph.14182

Palacio-López K, Rodríguez-López N. 2007. Plasticidad fenotípica en Lippia alba (Verbenaceae) en respuesta a la disponibilidad hídrica en dos ambientes lumínicos. Acta Biológica Colobiana 13: 187-198.

Peñaloza-Ramírez JM, González-Rodríguez A, MendozaCuenca L, Caron H, Kremer A, Oyama K. 2010. Interspecific gene flow in a multispecies oak hybrid zone in the Sierra Tarahuamra of Mexico. Annals of Botany 105: 389-399. DOI: https://doi.org/10.1093/aob/mcp301

Peterson AT, Navarro-Sigüenza AG. 2001. Alternate species concepts as bases for determining priority conservation areas. Conservation Biology 13: 427-431. DOI: https://doi.org/10.1046/j.1523-1739.1999.0130024 $\underline{27 . x}$

Pigliucci M. 2001. Phenotypic plasticity: beyond nature and nurture. Baltimore, USA: The John Hopkins University Press. 328 p. ISBN 0-8018-6788-6

Pinheiro F, Dantas-Queiroz MV, Palma-Silva C. 2018. Plant species complex as models to understand speciation and evolution: A review of South American studies. Critical Reviews in Plant Sciences 37: 54-80. DOI: https:// doi.org/10.1080/07352689.2018.1471565

Ramírez-Preciado RP, Gasca-Pineda J, Arteaga MC. 2019. Effects of global warming on the potential distribution ranges of six Quercus species (Fagaceae). Flora 251: 32-38. DOI: https://doi.org/10.1016/j.flora.2018.12.006

Ramírez-Toro W, Torres-Miranda A, González-Rodríguez A, Ruiz-Sánchez E, Luna-Vega I, Oyama K. 2017. A multicriteria analysis for prioritizing areas for conservation of oaks (Fagaceae: Quercus) in Oaxaca, southern Mexico. Tropical Conservation Sciences 10: 1-29. DOI: https://doi.org/10.1177/1940082917714227

Ramírez-Valiente JA, Sánchez-Gómez D, Aranda I, Valladares F. 2010. Phenotypic plasticity and local adaptation in leaf ecophysiological traits of 13 contrasting cork oak populations under different water availabilities. Tree Physiology 30: 618-627. DOI: https:// doi.org/10.1093/treephys/tpq013

Ramírez-Valiente JA, Cavender-Bares J. 2017. Evolutionary trade-offs between drought resistance mechanisms across a precipitation gradient in a 
seasonally dry tropical oak (Quercus oleoides). Tree Physiology 37: 889-901. DOI: https://doi.org/10.1093/ treephys/tpx064

Raposo MA, Stopiglia R, Brito GRR, Bockmann FA, Kirwan GM, Gayon J, Dubois A. 2017. What really hampers taxonomy and conservation? A riposte to Garnett and Christidis. Zootaxa 4317: 179-184. DOI: https://doi.org/10.11646/zootaxa.4317.1.10

Reeves PA, Richards CM. 2011. Species delimitation under the general lineage concept: An empirical example using wild north American hops (Cannabaceae: Humulus lupulus). Systematic Biology 60: 45-59. DOI: https:// doi.org/10.1093/sysbio/syq056

Rieseberg LH. 1997. Hybrid origins of plant species. Annual Review of Ecology and Systematics 28: 359-389. DOI: https://doi.org/10.1146/annurev.ecolsys.28.1.359

Rieseberg LH, Archer MA, Wayne RK. 1999. Transgressive segregation, adaptation and speciation. Heredity 83: 363-372. DOI: https://doi.org/10.1038/sj.hdy.6886170

Rodríguez-Correa H, Oyama K, Quesada M, Fuchs EJ, Goznález-Rodríguez A. 2018. Contrasting Patterns of Population History and Seed-mediated Gene flow in Two Endemic Costa Rican Oak Species. Journal of Heredity 109: 530-542. DOI: https://doi.org/10.1093/jhered/ esy011

Romero RS. 2006. Revisión taxonómica del complejo Acutifoliae de Quercus (Fagaceae) con énfasis en su representación en México. Acta Botánica Mexicana 76: 1-45. DOI: https://doi.org/10.21829/abm76.2006.1016

Rosell JA, Olson ME, Weeks A, De-Nova JA, Medina LR, Pérez CJ, Feria TP, Bómez-Bermejo R, Montero JC, Eguiarte LE. 2010. Diversification in species complexes: Test of species origin and delimitation in the Bursera simarouba clade of tropical trees (Burseraceae). Molecular Phylogenetics and Evolution 57: 798-811. DOI: https://doi.org/10.1016/j.ympev.2010.08.004

Ruiz-Sanchez E, Sosa V. 2010. Delimiting species boundaries within the Neotropical bamboo Otatea (Poaceae: Bambusoideae) using molecular, morphological and ecological data. Molecular Phylogenetics and Evolution 54: 344-356. DOI: https:// doi.org/10.1016/j.ympev.2009.10.035

Sabás-Rosales JL, Siqueiros-Delgado ME, Valencia-Ávalos S, Enriquez-Enriquez ED. 2017. Reconocimiento taxonómico de seis especies arbustivas de encinos (Quercus secc. Quercus: Fagaceae) Polibotanica 44: 11-38. DOI: http://dx.doi.org/10.18387/polibotanica.44.2

Sangster G. 2018. Integrative taxonomy of birds: the nature and delimitation of species. In: Tietze DT, ed. Bird Species, Fascinating Life Sciences. Gewerbestrasse, Suitzerland: Springer Cham, pp. 9-37. ISBN 978-3-319-91689-7. DOI: https://doi.org/10.1007/978-3 $\underline{-319-91689-7 \quad 2}$
Simeone MC, Piredda R, Papini A, Vesella F, Schirone B. 2013. Application of plastid and nuclear markers to DNA barcoding of Euro-Mediterranean oaks (Querucs, Fagaceae): problems, prospects and phylogenetic implications. Botanical Journal of the Linnean Society 172: 478-499. DOI: https://doi.org/10.1111/boj.12059

Sites JW Jr, Marshall JC. 2004. Operational criteria for delimiting species. Annual Review of Ecology Evolution and Systematics 35: 199-227. DOI: https://doi.org/ 10.1146/annurev.ecolsys.35.112202.130128

Song Y-G, Petitpierre B, Deng M, Wu J-P, Kozlowski G. 2019. Predicting climate change impacts on the threatened Quercus arbutifolia in montane cloud forests in southern China and Vietnam: Conservation implications. Forest Ecology and Management 444: 269-279. DOI: https://doi.org/10.1016/j.foreco.2019.04. $\underline{028}$

Sork V, Riordan E, Gugger PF, Fitz-Gibbon S, Wei Z, Ortego J. 2016. Phylogeny and introgression of California Scrub whit oaks (Quercus section Quercus). International Oaks 27: 61-74.

Spellenberg R, Bacon J. 1996. Taxonomy and distribution of a natural group of black oaks of Mexico (Quercus, section Lobatae, subsection Racemiflorae). Systematic Botany 21: 85-99 DOI: https://doi.org/10.2307/2419565

Stace CA. 1978. Breeding systems, variation patterns and species delimitation. In: Street HE, ed. Essays In Plant Taxonomy, London, England: Academic Press. pp57-78. ISBN: 0126733600, 9780126733600

Su X, Wu G, Li L, Liu J. 2015. Species delimitation in plants using the Qinghai-Tibet Plateau endemic Orinus (Poaceae: Tridentinae) as an example. Annals of Botany 116: 35-48. DOI: https://doi.org/10.1093/aob/mcv062

Sullivan AR, Owusu SA, Weber JA, Hipp AL, Gailing O. 2016. Hybridization and divergence in multi-species oak (Quercus) communities. Botanical Journal of the Linnean Society 181: 99-114. DOI: https://doi.org/ $\underline{10.1111 / \text { boj.12393 }}$

Torres-Miranda A, Luna-Vega I, Oyama K. 2011. Conservation biogeography of red oaks (Quercus, section Lobatae) in Mexico and central America. American Journal of Botany 98: 290-305. DOI: https:// doi.org/10.3732/ajb.1000218

Trelease W. 1924. The American oaks. Memoirs of the National Academy of Sciences 20: 1-255. DOI: https:// doi.org/10.5962/bhl.title.142965

Turland NJ, Wiersema JH, Barrie FR, Greuter W, Hawksworth DL, Herendeen PS, Knapp S, Kusber W-H, Li D-Z, Marhold K, May TW, McNeill J, Monro AM, Prado J, Price MJ, Smith GF, eds. 2018: International Code of Nomenclature for algae, fungi, and plants (Shenzhen Code). Shenzhen, China: Nineteenth International Botanical Congress. DOI: https://doi.org/ $\underline{10.12705 / \text { Code } 2018}$ 
Valladares F, Chico JM, Aranda I, Balaguer L, Dizengremel P, Manrique E, Dreyer E. 2002. The greater seedling high-light tolerance of Quercus robur over Fagus sylvatica is linked to a greater physiological plasticity. Trees 16: 395-403. DOI: https://doi.org/10.1007/s004 68-002-0184-4

Valencia-A, S. 2004. Diversidad del género Quercus (Fagaceae) en México. Boletín de la Sociedad Botánica de México 75: 33-53. DOI: https://doi.org/10.17129/ botsci.1692

Valencia-A S, Gual-Díaz M. 2014. La familia Fagaceae en el bosque mesófilo de montaña de México. Botanical Sciences 92: 193-204. DOI: https://doi.org/10.17129/ botsci.45

Valencia-A S, Flores-Franco G, Jiménez-Ramírez J. 2015. A nomenclatural revisión of Quercus acutifolia, $Q$. conspersa and Q. grahamii (Lobatae, Fagaceae). Phytotaxa 218: 289-294. DOI: https://doi.org/10.11646/ phytotaxa.218.3.7

Valencia-A S, Sabas R JL, Soto OJ. 2016. A new species of Quercus, section Lobatae (Fagaceae) from the Sierra Madre Oriental, Mexico. Phytotaxa 269: 120-126. DOI: https://doi.org/10.11646/phytotaxa.269.2.5

Valencia-Cuevas L, Piñero D, Mussali-Galante P, ValenciaÁvalos S, Tovar-Sánchez E. 2014. Effect of a red oak species gradient on genetic structure and diversity of Quercus castanea (Fagaceae) in Mexico. Tree Genetics
\& Genomes 10: 641-652. DOI: https://doi.org/10.1007/ $\underline{\text { s11295-014-0710-8 }}$

VanValen L. 1976. Ecological species, multispecies, and oaks. Taxon 25: 233-239. DOI: https://doi.org/10.2307/ $\underline{1219444}$

Vázquez ML, Nixon KC. 2013. Taxonomy of Quercus crassifolia (Fagaceae) and morphologically similar species in Mexico. Brittonia 65: 208-227. https:// www.jstor.org/stable/24692574

Viscosi V. 2015. Geometric morphometrics and leaf phenotypic plasticity: assessing fluctuating asymmetry and allometry in European white oaks (Quercus). Botanical Journal of the Linnean Society 179: 335-348. DOI: https://doi.org/10.1111/boj.12323

Williams JH, Boecklen WJ, Howard DJ. 2001. Reproductive processes in two oak (Quercus) contact zones with different levels of hybridization. Heredity 87: 680-690. DOI: https://doi.org/10.1046/j.1365-2540.200 1.00968.X

Zeng YF, Liao WJ, Petit RJ, Ahang DY. 2010. Explorign Species Limits in Two Closely Related chinese Oaks. Plos One 5: e15529. DOI: https://doi.org/10.1371/jour nal.pone.0015529

Zhang R, Hipp AL, Gailing O. 2015. Sharing of chloroplast haplotypes among red oak species suggests interspecific gene flow between neighboring populations. Botany 93: 691-700. DOI: https://doi.org/10.1139/cjb-2014-0261 